\title{
Leocratides (Annelida: Hesionidae) from the Pacific Coast of Middle Honshu, Japan, with a Description of Leocratides kimuraorum sp. nov.
}

\author{
Naoto Jimi ${ }^{1,4}$, Masaatsu Tanaka ${ }^{2,3}$, and Hiroshi Kajihara ${ }^{1}$ \\ ${ }^{1}$ Department of Natural History Sciences, Graduate School of Science, Hokkaido University, \\ Kita 10 Nishi 8 Kitaku, Sapporo, Hokkaido 060-0810, Japan \\ E-mail: beniimo7010@gmail.com \\ ${ }^{2}$ Department of Biology, Faculty of Science, Toho University, \\ 2-2-1 Funabashi, Chiba 274-8510, Japan \\ ${ }^{3}$ Department of Earth and Environmental Sciences, Faculty of Science, Kagoshima University, \\ 1-21-35 Korimoto, Kagoshima 890-0065, Japan \\ ${ }^{4}$ Corresponding author
}

(Received 29 March 2017; Accepted 13 June 2017)

http://zoobank.org/CD308AA8-CCA0-4831-B7CB-3052E946588F

\begin{abstract}
A new species of hesionid polychaetes, Leocratides kimuraorum sp. nov., is described based on material collected from the Shima Peninsula and Sagami Bay (middle Honshu, Japan), as well as museum specimens collected from Sagami Bay, Suruga Bay, and Shirahama. Leocratides kimuraorum sp. nov. is the third species in this genus and can be discriminated from the two congeners, L. filamentosus Ehlers, 1908 and L. ehlersi (Horst, 1921), by $i$ ) the length of the antennae, which are as long as palps, $i$ ) the presence of pharyngeal terminal papillae, and $i i i)$ the absence of a papillose peristomial membrane. On the other hand, L. filamentosus, originally described from off Western Sumatra, Indonesia, was also collected from Sagami Bay, and represents a new record of this species for Japanese waters. Partial mitochondrial cytochrome $c$ oxidase subunit I gene sequences from the holotype of L. kimuraorum sp. nov. and newly collected specimen of $L$. filamentosus are provided for reliable species identification in the future.
\end{abstract}

Key Words: Polychaeta, Phyllodocida, DNA barcode, COI, TRV Seisui-maru, JAMBIO, marine invertebrates, hexactinellid sponge, symbiosis, taxonomy.

\section{Introduction}

The hesionid polychaete genus Leocratides Ehlers, 1908 consists of two species, L. filamentosus Ehlers, 1908 and L. ehlersi (Horst, 1921), both of which were originally found among hexactinellid sponges from sublittoral substrates in Indonesian waters. The name-bearing types of the first species, L. filamentosus, were collected from Aphrocallistes beatrix Gray, 1858, off Nias Island at $677 \mathrm{~m}$ depth (Ehlers 1908). Leocratides filamentosus has also been reported from Japan (Imajima and Hartman 1964; Imajima 2003, 2005, 2006, 2007), New Caledonia (Rullier 1972), and Egypt (as L. filamentosa [sic]; Belal and Ghobashy 2012). The second species, originally described as Leocrates ehlersi and later combined with Leocratides by Fauvel (1932), was found among a species of Aphrocallistes Gray, 1858, collected at a depth of $274 \mathrm{~m}$ in Saleh Bay, north coast of Sumbawa, Indonesia (Horst 1921, 1924; Pettibone 1970). Besides the records for the type locality, L. ehlersi has also been reported from Sagami Bay of Japan (as Leocratides ehlersi; Hessle 1925), the Andaman Sea (Fauvel 1932, 1953), the Arabian Sea (Parulekar 1971), and the Red Sea (Fishelson and Rullier 1969; Amoureux et al. 1978).
The taxonomy within Leocratides is contentious. When Horst (1921) described L. ehlersi, he diagnosed the two Leocratides species as having one (in L. filamentosus) or two (in L. ehlersi) dorsal jaw plates. Based on examination of the two syntypes of L. filamentosus, however, Augener (1926) argued that $L$. ehlersi should be treated as a junior synonym of the former which has actually two dorsal jaw plates, instead of one. Later, Pettibone (1970) redescribed the syntypes of both species in detail and also concluded that they were synonymous. In contrast, also having examined the syntypes of the two, Pleijel (1998) restored L. ehlersi as a distinct species, concluding that the pharyngeal terminal papillae and the papillose peristomial membrane are both present in L. filamentosus, but are absent in L. ehlersi. In this study, we follow the taxonomy of Pleijel (1998), treating $L$. filamentosus and L. ehlersi as two distinct species.

While several authors have recorded Leocratides species from Japanese waters, the taxonomic identity of the Japanese taxon (or taxa) requires further scrutiny. Hessle (1925) reported six specimens of hesionids under the name "Leocrates ehlersi" from Sagami Bay (from $150 \mathrm{~m}$ to $600 \mathrm{~m}$ depths). Subsequently, Imajima and Hartman (1964) emended that record to "Leocratides filamentosus" without any explanation. Imajima $(2003,2005,2006,2007)$ also 
identified a number of hesionid specimens as L. filamentosus; these were collected from the Pacific coast of middle Honshu (around Sagami Bay and Suruga Bay) and South West Japan (off the Tokara Islands and the Amami Islands), collected at the depth of $74 \mathrm{~m}$ to $297 \mathrm{~m}$. Okanishi et al. (2016) reported "Leocratides sp." near Shirahama (from 164-169 m depth). As to the Japanese Leocratides species, however, the diagnostic characters mentioned earlier were neither explicitly mentioned by Hessle (1925) and Okanishi et al. (2016) nor clearly illustrated by Imajima (2003, 2005, 2006, 2007), making their taxonomic identity blurred.

NJ obtained specimens of Leocratides during a research cruise onboard the training and research vessel (TRV) Seisui-maru (Mie University) off the Shima Peninsula. Another specimen of Leocratides was also collected by MT in Sagami Bay. A close examination in the laboratory revealed that these specimens are morphologically consistent with the description and illustration of "L. filamentosus" by Imajima $(2003,2007)$ and also the illustration of "Leocrates ehlersi" by Hessle (1925), whereas they do not correspond with the original descriptions of L. filamentosus and L. ehlersi (Ehlers 1908; Horst 1921). In this paper, we describe these specimens along with some of the voucher material examined in Imajima $(2003,2007)$ and Okanishi et al. (2016) as the third member of Leocratides, providing barcode sequence of the holotype for the new species to facilitate future reliable identification.

In addition to the new species, we also found a number of specimens of L. filamentosus in the sense of Ehlers (1908) but not Imajima $(2003,2007)$ from Sagami Bay. In this paper, we give a redescription of $L$. filamentosus based on these specimens as representing a truly new record for Japanese waters.

\section{Materials and Methods}

Fresh specimens were newly collected from Sagami Bay and off the Shima Peninsula, Japan (Table 1). Some of the live specimens were photographed onboard with a digital camera (Nikon D60), then fixed in 10\% formalin-seawater or $70 \%$ ethanol. After preservation, these specimens were observed with a microscope (Nikon SMZ1500 and OLYMPUS BX51) and photographed with a digital camera (Nikon D5200). All the material has been deposited in the
National Museum of Nature and Science, Tsukuba (NSMT). Additionally, a part of Leocratides specimens investigated in Imajima $(2003,2007)$ and Okanishi et al. (2016), which have been kept in the NSMT, were also examined.

DNA extraction, and sequencing for partial sequences of mitochondrial cytochrome $c$ oxidase subunit I (COI) were carried out following the method of Jimi and Fujiwara (2016). Newly obtained sequences have been deposited in the DNA Data Bank of Japan.

\section{Systematics}

Genus Leocratides Ehlers, 1908

[New Japanese name: hanakago-otohime-gokai-zoku]

Leocratides kimuraorum sp. nov.

[New Japanese name: Kimura-hanakago-otohime-gokai (previously called “oni-otohime-gokai”)]

(Figs 1, 2)

?Leocrates ehlersi (non Horst, 1921); Hessle 1925: 14-15, fig. 3. Leocratides filamentosus (non Ehlers, 1908); Imajima and Hartman 1964: 82-83; Imajima 2003: 136-138, fig. 80 (in part); Imajima 2007: 444, fig. 138 (in part).

Leocratides sp.; Okanishi et al. 2016: 14.

Material examined. Holotype: NMST-Pol H-622, $29 \mathrm{~mm}$ long, $5 \mathrm{~mm}$ wide, sex unknown, off Shima Peninsula, St. 1, 103-104 m depth, 12 October 2016, collected by NJ (right parapodium of chaetiger 5 was removed for observation; it is preserved in $70 \%$ ethanol in a $2.0 \mathrm{ml}$ plastic tube, which is contained in the same glass vial together with the rest of the body). Paratypes (14 specimens): NSMT-Pol P-623-624, five specimens, 11-19 mm long, $2 \mathrm{~mm}$ wide, sex unknown, off Shima Peninsula, St. 1 (NSMT-Pol P-623, four specimens) and St. 2 (NSMT-Pol P-624, one specimen), 12 October 2016, collected by NJ; NSMT-Pol P-625, one specimen, $25 \mathrm{~mm}$ long, $4 \mathrm{~mm}$ wide, male (sperm present in each segment's gonads), Sagami Bay St. 2, 104-111 m depth, 27 April 2016, collected by MT; NSMT-Pol P-626, three specimens examined by Okanishi et al. (2016), 6-16 mm long, $2 \mathrm{~mm}$ wide, sex unknown, off Shirahama, 164-169 m depth, 27 May 2015, collected by NJ; NSMT-Pol R 176, two specimens examined by Imajima (2003, 2007), 21-24 mm long, $3 \mathrm{~mm}$ wide, sex unknown, Sagami Bay, 110-120m

Table 1. Collection data of Leocratides spp. in this study.

\begin{tabular}{|c|c|c|c|c|c|c|}
\hline Locality & Latitude & Longitude & Depth (m) & Collection date & Collected species & Contained sponges \\
\hline Sagami Bay, St. 1 & $\begin{array}{c}35^{\circ} 07.132^{\prime} \mathrm{N} \text { to } \\
35^{\circ} 07.388^{\prime} \mathrm{N}\end{array}$ & $\begin{array}{c}139^{\circ} 33.709^{\prime} \mathrm{E} \text { to } \\
139^{\circ} 33.365^{\prime} \mathrm{E}\end{array}$ & $213-255$ & 29 June 2011 & Leocratides filamentosus & Unknown \\
\hline Sagami Bay, St. 2 & $\begin{array}{c}35^{\circ} 07.5787^{\prime} \mathrm{N} \text { to } \\
35^{\circ} 07.5583^{\prime} \mathrm{N}\end{array}$ & $\begin{array}{c}139^{\circ} 33.7096^{\prime} \mathrm{E} \text { to } \\
139^{\circ} 33.8756^{\prime} \mathrm{E}\end{array}$ & $104-111$ & 27 April 2016 & $\begin{array}{l}\text { Leocratides kimuraorum } \\
\text { sp. nov. }\end{array}$ & Hexactinellid sponge \\
\hline Sagami Bay, St. 3 & $\begin{array}{c}35^{\circ} 06.929^{\prime} \mathrm{N} \text { to } \\
35^{\circ} 06.631^{\prime} \mathrm{N}\end{array}$ & $\begin{array}{c}139^{\circ} 33.814^{\prime} \mathrm{E} \text { to } \\
139^{\circ} 33.734^{\prime} \mathrm{E}\end{array}$ & $292-375$ & 15 February 2017 & Leocratides filamentosus & Aphrocallistes sp. \\
\hline $\begin{array}{l}\text { Off Shima Peninsula, } \\
\text { St. } 1\end{array}$ & $\begin{array}{c}34^{\circ} 11.63^{\prime} \mathrm{N} \text { to } \\
34^{\circ} 11.66^{\prime} \mathrm{N}\end{array}$ & $\begin{array}{c}136^{\circ} 42.56^{\prime} \mathrm{E} \text { to } \\
136^{\circ} 42.69^{\prime} \mathrm{E}\end{array}$ & $103-104$ & 12 October 2016 & $\begin{array}{l}\text { Leocratides kimuraorum } \\
\text { sp. nov. }\end{array}$ & $\begin{array}{l}\text { Demosponge and hexacti- } \\
\text { nellid sponge }\end{array}$ \\
\hline $\begin{array}{l}\text { Off Shima Peninsula, } \\
\text { St. } 2\end{array}$ & $\begin{array}{l}34^{\circ} 11.81^{\prime} \mathrm{N} \text { to } \\
34^{\circ} 11.82^{\prime} \mathrm{N}\end{array}$ & $\begin{array}{c}136^{\circ} 41.80^{\prime} \mathrm{E} \text { to } \\
136^{\circ} 41.95^{\prime} \mathrm{E}\end{array}$ & 107 & 12 October 2016 & $\begin{array}{l}\text { Leocratides kimuraorum } \\
\text { sp. nov. }\end{array}$ & $\begin{array}{l}\text { Demosponge and hexacti- } \\
\text { nellid sponge }\end{array}$ \\
\hline
\end{tabular}


depth, 14 March 1954, collected by the late Emperor Showa; NSMT-Pol R 968, one specimen examined by Imajima (2003, 2007), $21 \mathrm{~mm}$ long, $3 \mathrm{~mm}$, sex unknown, Sagami Bay, 85-90 m depth, 24 January 1965, collected by the late Emperor Showa; NSMT-Pol P-627: one specimen examined by Imajima (2007), $16 \mathrm{~mm}$ long, $3 \mathrm{~mm}$ wide, sex unknown, Suruga Bay, $92 \mathrm{~m}$ depth, 4 October 1995, collected by the late Dr. Minoru Imajima (MI); NSMT-Pol P-628: one specimen examined by Imajima (2007), $24 \mathrm{~mm}$ long, $3 \mathrm{~mm}$ wide, sex unknown, Suruga Bay, 86-91 m depth, 8 February 1978, col- lected by MI.

Sequence. LC258082, COI gene, $630 \mathrm{bp}$, determined from the holotype.

Description. Holotype $29 \mathrm{~mm}$ long, $5 \mathrm{~mm}$ wide in chaetiger 7 (not including parapodia), 21 segments, 16 chaetigers. Body cylindrical, tapered in posterior region (Fig. 1A, B), transparent in life (Fig. 1A) and whitish in ethanol; dorsal integument annulated, with 15-17 transverse wrinkles per segment. Dorsum with numerous, thin, transverse discontinuous brown lines, extended into lateral cushions,

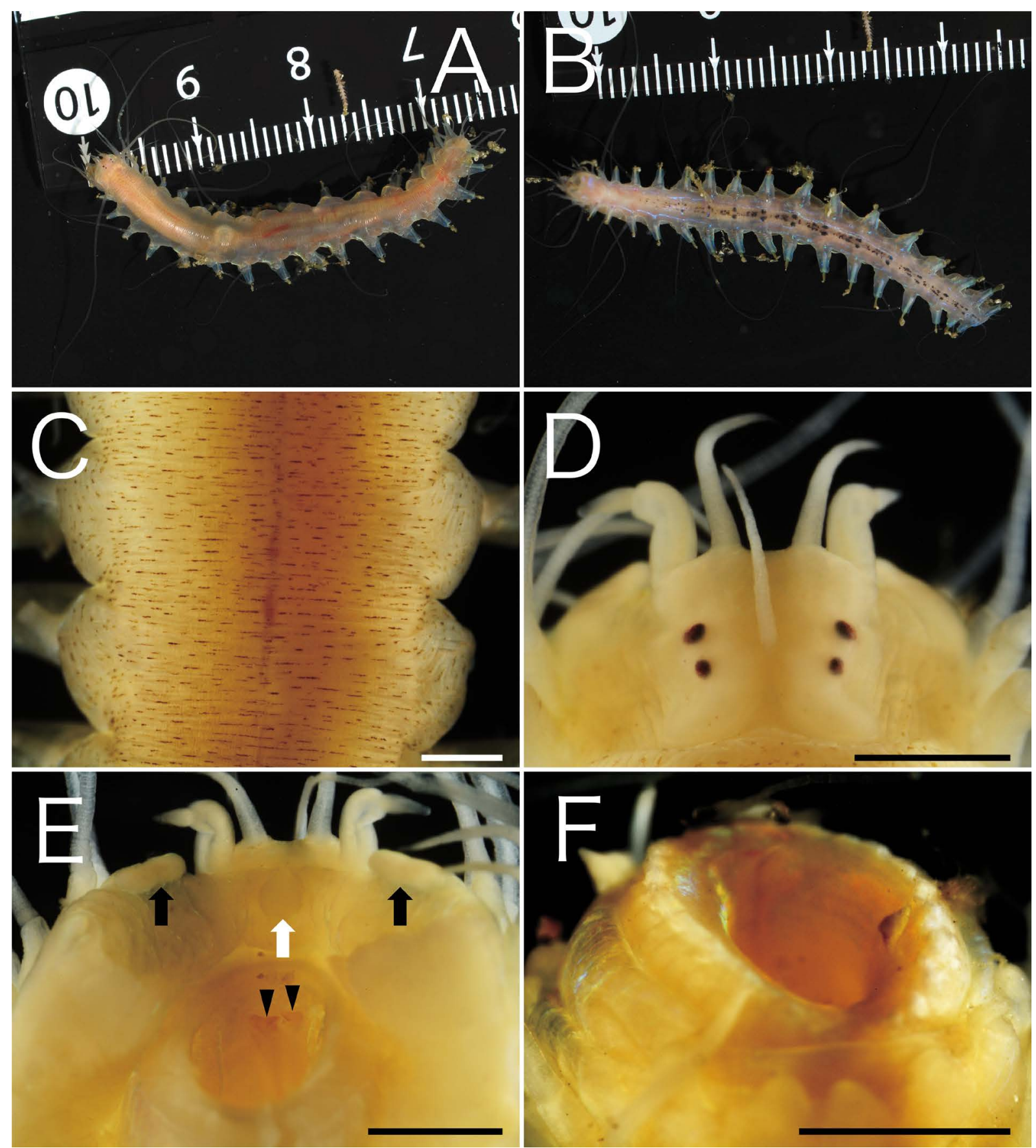

Fig. 1. Leocratides kimuraorum sp. nov., holotype, NSMT-Pol H-622. A, Live specimen, dorsal view; B, same, ventral view; C, integument and lateral cushions in chaetigers $4-5$, dorsal view; D, prostomium, dorsal view; E, pharynx and peristomium, ventral view, showing facial tubercle (white arrow), cushion-shaped appendages (black arrows), and dorsal jaw plates (arrowheads); F, pharynx with terminal papillae, ventral view. Scale of the ruler: A, B, $1 \mathrm{~mm}$. Scale bars: C-F, $1 \mathrm{~mm}$. 
varying in length, decreasing in size laterally (Fig. 1A, C); ventrally, black spots of different size and shape arranged along mid-ventral groove, in chaetal lobe regions, two larger spots better developed along chaetigers 4-15 (Fig. 1B). Prostomium rectangular, slightly wider than long, mid-dorsally with shallow depression, square in shape from dorsal view (Fig. 1D). Median antenna cirriform, smooth, tapered, inserted in central part of prostomium, extended beyond anterior prostomial margin, 1.1 times longer (and thinner) than lateral antenna, surpassing palpophores. Lateral antennae tapered, smooth, on anterior edge of prostomium. Palps bi-articulated, 0.9-1 times longer than lateral antennae, palpophore two times longer than palpostyle, bent laterally, pointed to body sides, external to antennae (Fig. 1D). Eyes brownish, two pairs, on mid-lateral part of prostomium; an- terior pair slightly larger and more separated than posterior one (Fig. 1D). Facial tubercle present mid-ventrally on prostomium; cushion-shaped appendage present between palps and tentacular cirri on each side (Fig. 1E); papillose peristomial membrane absent.

Tentacular cirri eight pairs, long, thick; longest one reaching chaetiger 10. Lateral cushions low, barely projected dorsally, slightly projected laterally, undivided, with 17-18 longitudinal wrinkles per side (Fig. 1C).

Parapodia uniform throughout; with chaetal lobes tapered, truncate, as long as wide (Fig. 2A); dorsal cirri with cirrophores, latter being cylindrical, smooth, about twice longer than wide (Fig. 2B); cirrostyle very long, whip-like, smooth basally, annulated medially and distally, longer than body width (including parapodia). Ventral cirri basally
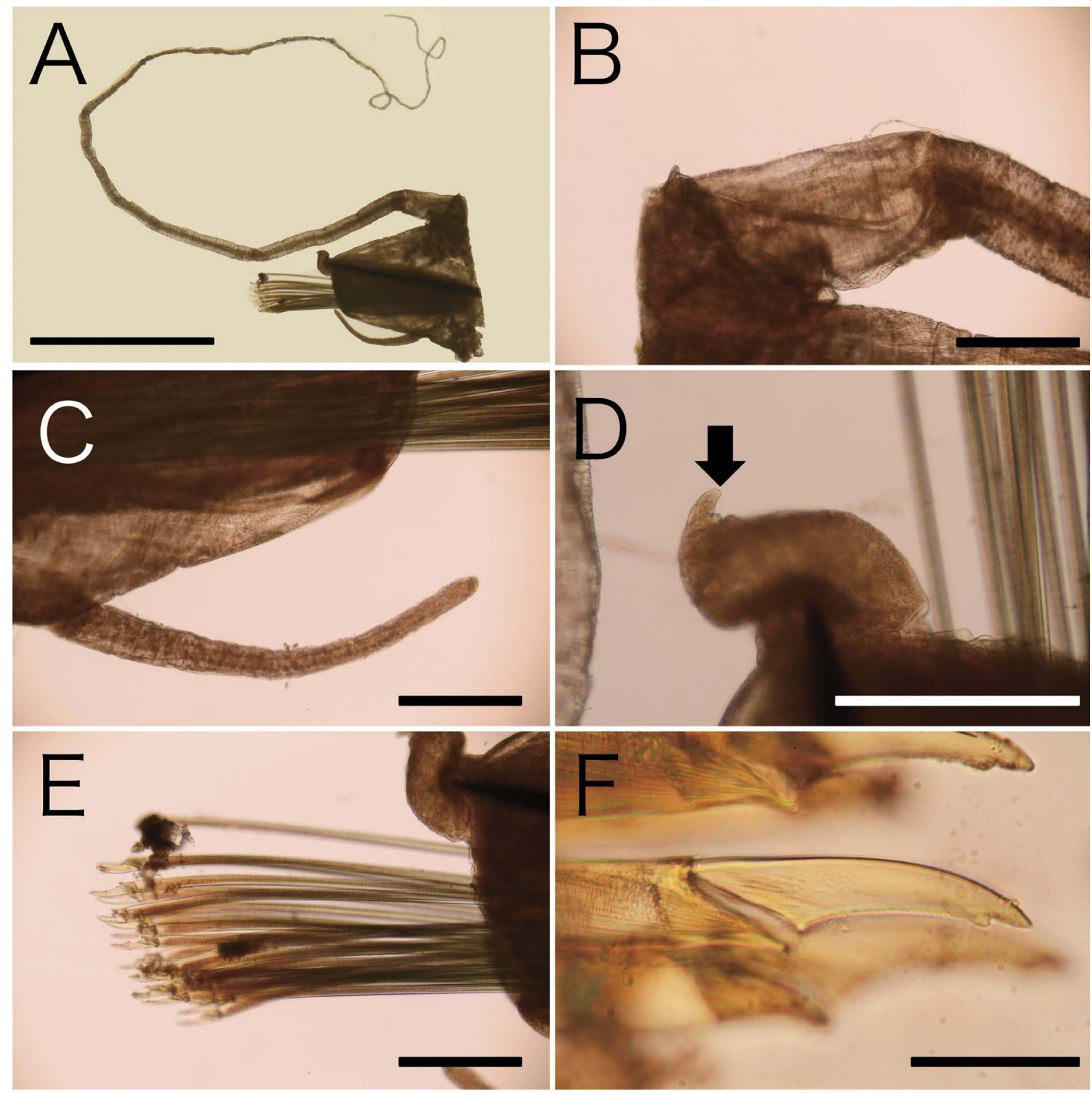

Fig. 2. Leocratides kimuraorum sp. nov., right parapodium of chaetiger 5, holotype, NSMT-Pol H-622. A, General appearance of parapodium, anterior view; B, cirrophore; C, ventral cirrus; D, acicular lobe, arrow indicating its tip, the base side of photo is the parapodial tip; E, bundle of neurochaetae; F, blade of neurochaeta. Scale bars: A, $2 \mathrm{~mm}$; B-E, $300 \mu \mathrm{m}$; F, $50 \mu \mathrm{m}$. 
smooth, rugose medially and distally, surpassing chaetal lobe, reaching up to half length of neurochaetal bundle (Fig. 2C).

Neuropodial acicula black, tapered; acicular lobe single, thick, digitate, tapered into a small mucro (Fig. 2D). Neurochaetae about 20 per bundle (Fig. 2E); handle greenish; blade pale brownish, bidentate, 5 times longer than wide; with subdistal tooth short, blunt, 0.4 times longer than apical tooth; guard tooth absent (Fig. 2F).

Cirri of prepygidial segment broken; pygidium smooth, depressed, with paired cirri; anus located dorso-terminally, with about 10 anal papillae.

Pharynx dissected in holotype, about 20 low cushion-like terminal papillae present (Fig. 1F); dorsal jaw two plates, ventral jaw one plate.

Variation. Dorsal transverse lines and ventral black spots faded in some paratype specimens.

Etymology. The specific name is a noun in the genitive plural, after a Japanese marine ecologist Dr. Taeko Kimura and a malacologist Mr. Shoichi Kimura, who organized the cruise of the TRV Seisui-maru of Mie University, during which a part of the type specimens, including the holotype, of the new species were collected.

Distribution. Pacific coast of middle Honshu, Japan: 85-169 m depth, collected with hexactinellid sponges.

Remarks. Our specimens undoubtedly belong to Leocratides because their body consists of 21 segments, the anterior cirri are in eight pairs, the neurochaetae are bidentate, the palps are bi-articulated, the parapodia are uniramous, and the jaws are present, all agreeing with the generic diagnosis provided by previous researchers (Pettibone 1970; Pleijel 1998; Rizzo and Salazar-Vallejo 2014; Salazar-Vallejo 2016).

Leocratides kimuraorum sp. nov. differs from L. filamentosus in the lateral antennae because they are as long as palps in L. kimuraorum sp. nov. but shorter than palps in L. filamentosus, and there is no papillose peristomial membrane in L. kimuraorum sp. nov. whereas it is present in L. filamentosus. It can also be distinguished from L. ehlersi by the pharyngeal terminal papillae (present in L. kimuraorum sp. nov. vs. absent in L. ehlersi) (Horst 1921; Pleijel 1998).

Because we were not able to examine Hessle's (1925) voucher material from Misaki, identified as "Leocrates ehler$s i$, its taxonomic identity remains uncertain, inasmuch as the morphological features illustrated in his figure (Hessle 1925: fig. 3) apply both to L. ehlersi and L. kimuraorum sp. nov.

We examined some of Imajima's $(2003,2007)$ voucher material from Sagami and Suruga Bays and noticed that his descriptions contain several errors. For instance, Imajima $(2003,2007)$ noted that there were two to five transverse wrinkles on the dorsal integument in each segment, whereas there are actually 15-17 wrinkles per segment. When it comes to the pharyngeal terminal papillae, Imajima (2003, 2007) stated that these were absent, although the papillae are in fact present in his voucher specimens. Therefore, we can confidently regard his material as belonging to L. kimuraorum sp. nov.
Leocratides filamentosus Ehlers, 1908

[New Japanese name: hanakago-otohime-gokai]

(Figs 3, 4)

Leocratides filamentosus Ehlers, 1908: 63, pl. 6, figs 8-12; Pettibone 1970: 230-231, figs 27-28; Pleijel 1998: 112.

?Leocratides filamentosus; Rullier 1972: 58; Imajima 2005: 82; 2006: 351; Belal and Ghobashy 2012: 178 (as $L$. filamentosa $[$ sic $]$ ).

Material examined. Nine specimens: NMST-Pol 113219, one specimen, sex unknown, Sagami Bay, St.1, 213-255 m depth, 29 June 2011, collected by MT (right parapodium of chaetiger 10 removed for observation; preserved in $70 \%$ ethanol in a $2.0 \mathrm{ml}$ plastic tube, kept in the same vial together with the rest of the body); NSMT-Pol 113220, eight specimens, one female and others of unknown sex, Sagami Bay, St. 3, 292-375 m depth, 15 February 2017, collected by NJ, MT, HK.

Sequence. LC258083, COI gene, 592 bp, determined from a specimen of NSMT-Pol 113220.

Description. $14-30 \mathrm{~mm}$ long, $2-4 \mathrm{~mm}$ wide in chaetiger 7 (not including parapodia), 21 segments, 16 chaetigers; right parapodium of chaetiger 10 removed for observation. Body cylindrical, tapered in posterior region, transparent in live (Fig. 3A, B), whitish in ethanol; dorsal integument annulated, with 12-17 transverse wrinkles per segment. Brown lines on dorsal surface absent (Fig. 3A, $\mathrm{C})$; ventrally with black spots of varying size and shape arranged along median groove, in some places roughly on two rows, in chaetigers 5-16; some spots being particularly larger than others, arranged laterally in pair along line between parapodia in each segment, especially prominent in chaetigers 7-11 (Fig. 3B). Prostomium rectangular, longer than wide, mid-dorsally with shallow depression, square in shape from dorsal view (Fig. 3D). Median antenna conical, smooth, in central part of prostomium, not reaching anterior prostomial margin, 1.3 times longer than lateral antennae. Lateral antennae conical, smooth, on anterior edge of prostomium. Palps bi-articulated, 1.2 times longer than lateral antennae, palpophore four times longer than palpostyle, ventral to antennae (Fig. 3D). Eyes brownish, two pairs, on mid-lateral part of prostomium, anterior pair slightly larger and more separated than posterior one (Fig. 3D). Facial tubercle present mid-ventrally on prostomium; papillose peristomial membrane present (Fig. 3E).

Tentacular cirri eight pairs, long, thick; longest one reaching chaetiger 6. Lateral cushions low, barely projected dorsally, slightly projected laterally, undivided, with 7-8 longitudinal wrinkles per one lateral cushion (Fig. 3C).

Parapodia uniform throughout; chaetal lobes cylindrical, truncate, as long as wide (Fig. 4A); dorsal cirri with cirrophores cylindrical, smooth, 1.3 times longer than wide (Fig. 4B); cirrostyle whip-like, smooth, annulated, longer than body width (without parapodia). Ventral cirri basally rugose, surpassing chaetal lobe, reaching up to half length of neurochaetal bundle (Fig. 4C).

Neuropodial acicula black, tapered; acicular lobe single, 


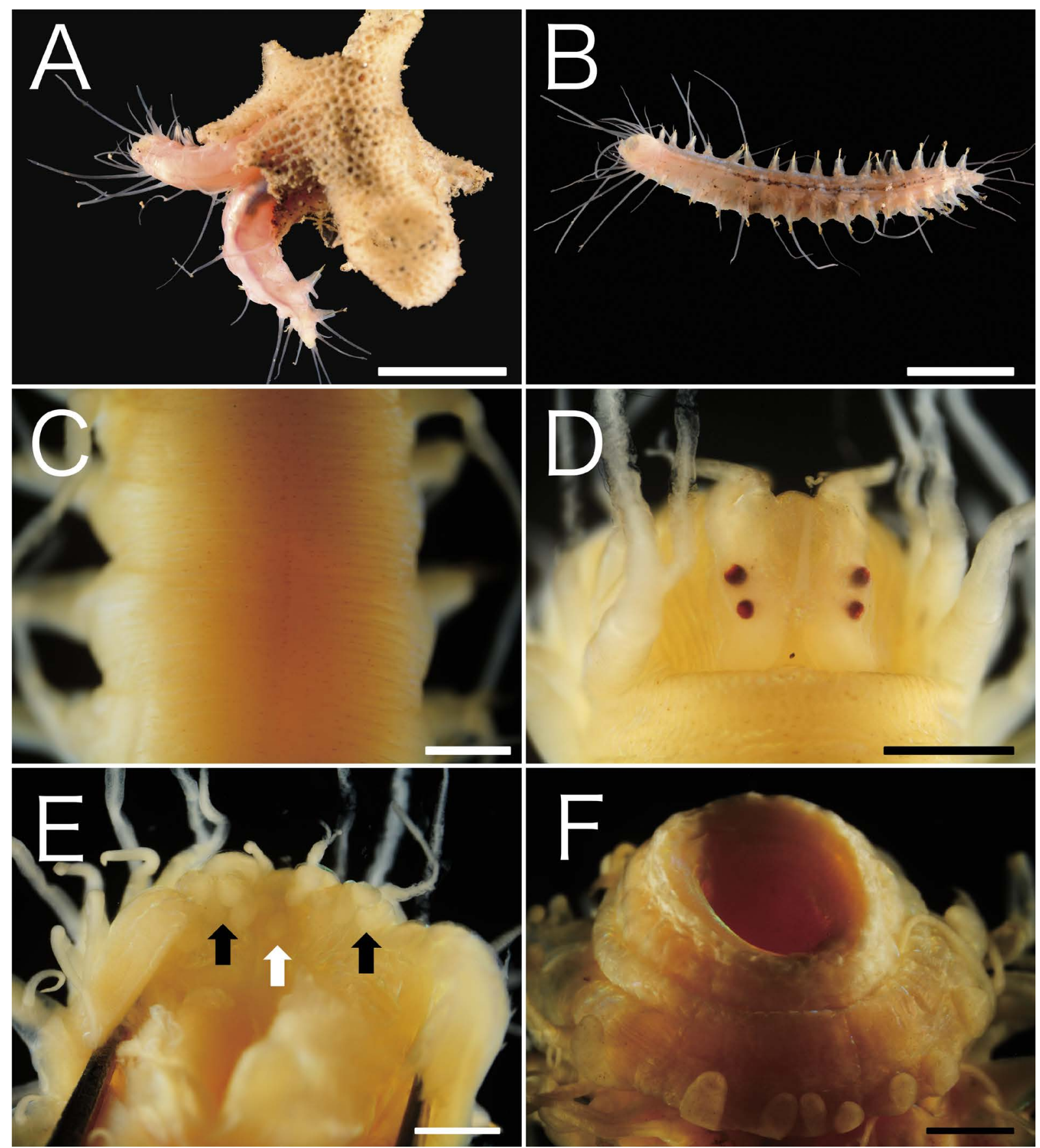

Fig. 3. Leocratides filamentosus Ehlers, 1908. A, B, F; NSMT-Pol 113220, C-E; NSMT-Pol 113219. A, Live specimen inside a fragment of an Aphrocallistes sp. hexactinellid sponge, dorsal view; B, same specimen, ventral view; C, integument and lateral cushions in chaetigers 2-4, dorsal view; D, prostomium, dorsal view; E, pharynx and peristomium, ventral view, showing facial tubercle (white arrow) and papillose peristomial membrane (black arrows); F, pharynx with terminal papillae, ventral view. Scale bars: A, B, $10 \mathrm{~mm}$; C-F, $1 \mathrm{~mm}$.

wider basally, tip digitate, long (Fig. 4D). Neurochaetae about 20 per bundle (Fig. 4E); handle greenish; blade yellowish, bidentate, six times longer than wide; with subdistal tooth 0.5 times longer than apical tooth; guard absent (Fig. 4F).

Cirri of prepygidial segment broken; pygidium smooth, depressed, with paired cirri; anus dorso-terminal, with about eight anal papillae.

Pharynx dissected, about 20 terminal low cushion-like terminal papillae present (Fig. 3F); dorsal jaw two plates, ventral jaw one plates.
Confirmed distribution. From Sagami Bay, Japan to Indonesia, 213-677 $\mathrm{m}$ depth, in hexactinellid sponges.

Remarks. Imajima (2003, 2007) reported "Leocratides filamentosus" from Japanese waters. However, as indicated above Imajima's $(2003,2007)$ specimens from Sagami and Suruga Bays actually belong to L. kimuraorum sp. nov. Imajima $(2005,2006)$ also reported "L. filamentosus" from off Izu-Oshima Island, Sagami Bay, and several other localities off the Nansei Islands, southwestern Japan, but neither morphological accounts nor the basis of his identifications were provided. We searched unregistered polychaete collec- 


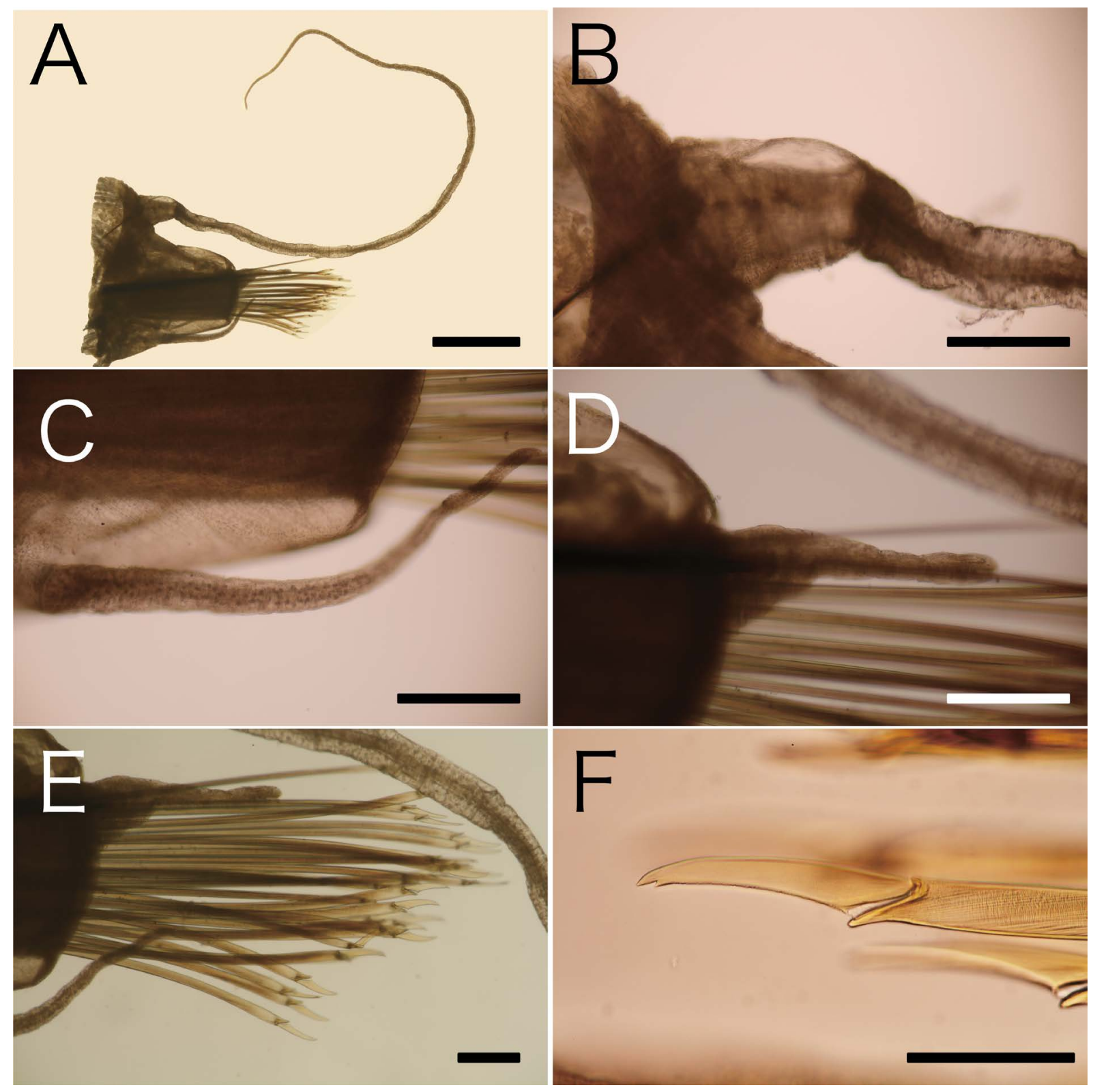

Fig. 4. Leocratides filamentosus Ehlers, 1908. Right parapodium of chaetiger 10, NSMT-Pol 113219. A, General appearance of parapodium, posterior view; B, cirrophore; C, ventral cirrus; D, acicular lobe; E, bundle of neurochaetae; F, blade of neurochaeta. Scale bars: A, $1 \mathrm{~mm}$; B-E, $300 \mu \mathrm{m} ; \mathrm{F}, 100 \mu \mathrm{m}$.

tion in NSMT for the voucher specimens that substantiate Imajima's $(2005,2006)$ records of his "L. filamentosus" from Izu-Oshima Island, Sagami Bay, and the Nansei Islands, but were not able to locate them. This makes the validity of these records of "L. filamentosus" rather obscure. Thus, we conclude that there has been no reliable distributional records of L. filamentosus from Japanese waters and this study represents the first record of the species for Japan.

Out of the type locality and Japanese waters, Rullier (1972) and Belal and Ghobashy (2012) also reported "Leocratides filamentosus" from extremely shallow depths (up to $8 \mathrm{~m}$ depth) in New Caledonia and Lake Timsah of the Suez Canal, Egypt, respectively. However, these studies provided only a brief account or an inadequate illustration and we consider these records are doubtful.

\section{Discussion}

An ecological association of Leocratides with hexactinellid sponges has been indicated because the two previously known species, L. filamentosus and L. ehlersi, were both found among Aphrocallistes hexactinellids (e.g., Pettibone 1970; this study). Our specimens of L. kimuraorum sp. nov. were also found among sediments which contained fragments of hexactinellid sponges, indicating that Leocratides species are generally associated with hexactinellids. Because dredging inevitably disturbs natural habitat, future studies aiming to observe specimens in-situ using a remotely operated vehicle, could reveal the ecology of Leocratides and the interaction between the worms and the host hexactinellid sponges. 
In this study, we found that the bathymetric distributions of L. kimuraorum sp. nov. and L. filamentosus seem to be clearly separated. In Sagami Bay, the two species were obtained almost sympatrically, but L. kimuraorum sp. nov. occurred in shallow waters, around $100-150 \mathrm{~m}$ depth, while $L$. filamentosus tended to occur in deeper waters, more than $200 \mathrm{~m}$ depth (Table 1). Recent studies focused on cryptic diversity of polychaetes indicate that depth may play an important role in speciation (Nygren et al. 2005, 2010; Schüller 2011; Nygren 2014; Oug et al. 2017); this scenario may be true for Leocratides. Further efforts combining the records of Leocrates species from various localities are required to reveal the nature of species distribution.

\section{Acknowledgments}

$\mathrm{NJ}$ is grateful for all their help in collecting the specimens to the captain and crew of the TRV Seisui-maru, Dr. Taeko Kimura, Mr. Shoichi Kimura, and Ms. Haruka Onishi (Mie University), Mr. Akito Ogawa (The University of Tokyo), Ms. Luna Yamamori (Kyoto University), and the member of the Marine Ecology Laboratory and other students of Mie University who participated the research cruise, Dr. Akira Asakura (Kyoto University), Dr. Katsumi Miyazaki (Niigata University), Dr. Masanori Okanishi (Ibaraki University), Dr. Asuka Sentoku (The University of Queensland), the member of the Shirahama Marine Research and crew of the R/V Janthina (Kyoto University). MT is indebted to Drs. Teruaki Nishikawa (Toho University) and Hiroshi Namikawa (NSMT) for giving him chance to participate their faunal survey in Sagami Bay, during which some specimens were found. We thank Drs. Hiroshi Namikawa and Hironori Komatsu (NSMT) for loan or searching of specimens under their care; Messrs. Mamoru Sekifuji, Hisanori Kohtsuka, and Dr. Akihito Omori (The University of Tokyo), Dr. Hiroaki Nakano and Mr. Yasutaka Tsuchiya (University of Tsukuba), and all the other participants in the 12th Japanese Association for Marine Biology (JAMBIO) Coastal Organism Joint Survey held at Misaki, for generous help in collecting additional material; Dr. Kevin Wakeman (Hokkaido University) for correcting the English; and Dr. Sergio I. Salazar-Vallejo and an anonymous reviewer for providing informative comments. This study was partly supported by JAMBIO.

\section{References}

Amoureux, L., Rullier, F., and Fishelson, L. 1978. Systematique et ecologie d'annelides polychetes de la presqu'il du Sinai. Israel Journal of Zoology 27: 57-163.

Augener, H. 1926. Ceylon-Polychäten (Fauna et Anatomia ceylanica, IV, Nr. 2). Jenaische Zeitschrift für Naturwissenschaft 62: 435-472.

Belal, A. A. M. and Ghobashy, A. F. A. 2012. Distribution of newly recorded benthic polychaetes in Timsah Lake, Suez Canal, Egypt. Egyptian Journal of Aquatic Research 38: 171-184.

Ehlers, E. 1908. Die bodensässigen Anneliden aus den Sammlungen der deutschen Tiefsee-Expedition. Pp. 1-167, pls 1-23. In: Chun, C.
(Ed.) Wissenschaftliche Ergebnisse der deutschen Tiefsee-Expedition auf dem Dempfer "Valdivia" 1898-1899, im Auftrage des Reichsamtes des Innern, Sechszehnter Band, Erste Lieferung. Gustav Fischer, Jena.

Fauvel, P. 1932. Annelida Polychaeta of the Indian Museum, Calcutta. Memoirs of the Indian Museum 12: 1-262, pls 1-8.

Fauvel, P. 1953. The Fauna of India including Pakistan, Ceylon, Burma and Malaya. Annelida Polychaeta. The Indian Press, Allahabad, 507 pp.

Fishelson, L. and Rullier, F. 1969. Quelques annelides polychetes de la Mer Rouge. Israel Journal of Zoology 18: 49-117.

Hessle, C. 1925. Einiges über die Hesioniden und die Stellung der Gattung Ancistrosyllis. Arkiv för Zoologi 17a: 1-36.

Horst, R. 1921. A review of the family of Hesionidae with a description of two new species. Zoologische Mededelingen 6: 73-83.

Horst, R. 1924. Polychaeta Errantia of the Siboga Expedition. Part III. Nereidae and Hesionidae. Siboga-Expeditie 24c: 145-198.

Imajima, M. 2003. Polychaetous annelids from Sagami Bay and Sagami Sea collected by the Emperor Showa of Japan and deposited at the Showa Memorial Institute, National Science Museum, Tokyo (II). Orders included within the Phyllodocida, Amphinomida, Spintherida and Eunicida. National Science Museum Monographs 23: $1-221$.

Imajima, M. 2005. Deep-sea benthic polychaetous annelids from around Nansei Islands. National Science Museum Monographs 29: 37-99.

Imajima, M. 2006. Polychaetous annelids from Sagami Bay and the Sagami Sea, central Japan. Memoirs of the National Science Museum 40: 317-408.

Imajima, M. 2007. Kankeidoubutsu Tamourui III [Annelida, Polychaeta, Vol. III]. Seibutsu Kenkyusya Co., Tokyo, v +499 pp. [In Japanese]

Imajima, M. and Hartman, O. 1964. The polychaetous annelids of Japan. Allan Hancock Foundation Publications, Occasional Paper 26: $1-452$.

Jimi, N. and Fujiwara, Y. 2016. New species of Trophoniella from Shimoda, Japan (Annelida, Flabelligeridae). ZooKeys 614: 1-13.

Nygren, A. 2014. Cryptic polychaete diversity: a review. Zoologica Scripta 43: 172-183.

Nygren, A., Eklöf, J., and Pleijel, F. 2010. Cryptic species of Notophyllum (Polychaeta: Phyllodocidae) in Scandinavian waters. Organisms Diversity \& Evolution 10: 193-204.

Nygren, A., Pleijel, F., and Sundberg, P. 2005. Genetic relationships between Nereimyra punctata and N. woodsholea (Hesionidae, Polychaeta). Journal of Zoological Systematics and Evolutionary Research 43: 273-276.

Okanishi, M., Sentoku, A., Fujimoto, S., Jimi, N., Nakayama, R., Yamana, Y., Yamauchi, H., Tanaka, H., Kato, T., Kashio, S., Uyeno, D., Yamamoto, K., Miyazaki, K., and Asakura, A. 2016. Marine benthic community in Shirahama, southwestern Kii Peninsula, central Japan. Publication of the Seto Marine Biological Laboratory 44: 7-52.

Oug, E., Bakken, T., Kongsrud, J. A., and Alvestad, T. 2017. Polychaetous annelids in the deep Nordic Seas: strong bathymetric gradients, low diversity and underdeveloped taxonomy. Deep-Sea Research II 137: 102-112.

Parulekar, A. H. 1971. Polychaetes from Maharashtra and Goa. Journal of the Bombay Natural History Society 68: 726-749, pls 1-4.

Pettibone, M. H. 1970. Polychaeta Errantia of the Siboga Expedition. Some additional polychaetes of the Polynoidae, Hesionidae, Nereidae, Goniadidae, Eunicidae, and Onuphidae, selected as new species by the late Dr. Hermann Augener with remarks on other related species. Siboga-Expeditie 24d: 199-270. [Pp. 1-72 in another pagination] 
Pleijel, F. 1998. Phylogeny and classification of Hesionidae (Polychaeta). Zoologica Scripta 27: 89-163.

Rizzo, A. E. and Salazar-Vallejo, S. I. 2014. Hesionidae Grube, 1850 (Annelida: Polychaeta) from South-Southeastern Brazil, with descriptions of four new species. Zootaxa 3856: 267-291.

Rullier, F. 1972. Annélides polychètes de Nouvelle-Calédonie recueillies par Y. Plessis et B. Salvat. Expédition Française sur les Récifs Cor- alliens de la Nouvelle-Calédonie 6: 6-169.

Salazar-Vallejo, S. I. 2016. Elisesione, a new name for Wesenbergia Hartman, 1955, and the description of a new species (Annelida, Hesionidae). ZooKeys 632: 1-12.

Schüller, M. 2011. Evidence for a role of bathymetry and emergence in speciation in the genus Glycera (Glyceridae, Polychaeta) from the deep Eastern Weddell Sea. Polar Biology 34: 549-564. 